\title{
Evidence for a Constitutive Cutinase in Ungerminated Conidia of Erysiphe necator Schwein
}

\author{
Sylvain Schnee, Erwan Rougeux, Roger Pezet, Olivier Viret and Katia Gindro*
}

Agroscope Changins-Wädenswil, P.O. Box 1012, Route de Duillier 50, CH-1260 Nyon, Switzerland

\begin{abstract}
Soluble proteins of ungerminated conidia of Erysiphe necator exhibited esterase and cutinase activities, and such hydrolytic activities were measured in the parietal protein fraction. However, histochemical localisation of esterase activity was detected upon further fungal development, as well in elongating germ tubes and in appressoria. The esterase activity was spectrophotometrically quantified using para-nitrophenylbutyrate as a substrate, and cutinase activity was determined using ${ }^{3} \mathrm{H}$-labelled cutin. Histochemical localisation was determined using indoxyl acetate as a substrate. Diisopropyl fluorophosphate was used as inhibitor of serine hydrolase. The role of a putative constitutive parietal cutinase in the ungerminated conidia of $E$. necator in adhesion to the host and differentiation of infective structures, as well as implications for successful penetration, are discussed.
\end{abstract}

Keywords: Cutinase; Esterase; $\left({ }^{3} \mathrm{H}\right)$ Cutin; Powdery mildew; Erysiphe necator; Vitis vinifera

\section{Introduction}

All plant organs are covered by a cuticular layer composed mainly of cutin, which forms the structural component of the cuticle in higher plants. Cutin is a complex polymer of epoxy and hydroxy fatty acids, which can be hydrolysed by specific serine esterases, i.e., cutinases [1]. The plant cuticle of aerial organs constitutes the first physical and chemical barrier that fungal phytopathogens must overcome to successfully infect their host. Recently, cutinase activity was discovered in the bacterium Thermobifida fusca that displayed the same affinity for substrates as Fusarium sp. but with a better thermostability [2]. Fungal pathogens have perfected different strategies to attach to the cuticular surface and then to penetrate the epidermal layer. The secretion of cutinolytic enzymes during the first steps of the infection process participates in spore attachment and the depolymerisation of the cutin complex, generating an entrance to the host cell [3]. The differentiation of infectious structures on the plant cuticle is also associated with the synthesis of esterases [4]. For example, esterases and cutinases contribute to the attachment of uredospores of Uromyces vicia-fabae to the host surface [5]. During the germination process, the conidia of Blumeria graminis liberates exudates containing esterases [6] and a pool of extracellular hydrolytic enzymes (e.g., cutinases) in response to a contact stimulus, leading to cutin hydrolysis and cutin monomer liberation $[7,8]$. A number of specific monomers of cutin activate the conidia germination and appressorium differentiation in Magnaporthe grisea [9].

Previous work of Heintz and Blaich [10] has suggested that the host penetration by Erysiphe necator, one of the major fungal disease of cultivated Vitis species, is mainly the result of mechanical pressure from the infectious hyphae. However, several species of the genus Erysiphe and other powdery mildews can synthesise enzymes that initiate the depolymerisation of the host plant cuticle and cell wall $[7,11]$. The aim of the present work was to demonstrate the presence of a constitutive cutinolytic enzyme in the conidia of E. necator. The role of cutinase in E. necator infection of grapevine and its overall role in the hostpathogen interaction are discussed.

\section{Material and Methods}

\section{Organisms and growth conditions}

Cuttings were obtained from Vitis vinifera L. cv. Chasselas cultivated in the experimental vineyards of Agroscope ChanginsWädenswil (Switzerland). Rooted plants were grown in the greenhouse as previously described by Pezet et al. [12]. When 10 leaves had developed, plants were placed in a growth chamber under alternating light $\left(16 \mathrm{~h}, 22^{\circ} \mathrm{C}\right)$ and dark $\left(8 \mathrm{~h}, 18^{\circ} \mathrm{C}\right)$ under $60 \%$ relative humidity. When plants reached the 15 leaf-stage, the fully developed leaves were used for further experiments. Detached leaves were sterilised by incubation in a $4 \%(\mathrm{w} / \mathrm{v})$ calcium hypochlorite aqueous solution for 10 min, rinsed once with sterile distilled water and placed in Petri dishes (abaxial surface towards the medium) containing water agar $(20 \mathrm{~g} / \mathrm{l})$ supplemented with benzimidazole $(30 \mathrm{mg} / \mathrm{l})$. As a primary inoculum, $E$. necator conidia were collected from infected leaves in the vineyards and were used to artificially inoculate the adaxial surface of the leaves. The leaves were inoculated by dispersing conidia from sporulating zones of E. necator by a slight blowing using a mini labour-pump. Conidia from 2-week-old infected leaves were harvested by vacuum aspiration [13] using a bioaerosol sampler [14] and immediately stored dry at $-80^{\circ} \mathrm{C}$ in cryotubes until use.

\section{Extraction of proteins and enzyme assays}

Cell wall proteins were extracted from $100 \mathrm{mg}$ of ungerminated conidia harvested as described above. These proteins were suspended in $10 \mathrm{ml}$ phosphate buffer $1 \mathrm{M} \mathrm{pH} 7.5$ with $1 \%$ Triton X-100, incubated for $24 \mathrm{~h}$ at $4^{\circ} \mathrm{C}$ under constant agitation and centrifuged $\left(10,000 \mathrm{rpm}, 4^{\circ} \mathrm{C}\right.$, $10 \mathrm{~min}$ ). The supernatant, corresponding to the parietal protein extract (PPE), was placed in dialysis tubing and concentrated in polyethylene glycol (PEG 20,000) to $1 \mathrm{ml}$ and stored at $-20^{\circ} \mathrm{C}$ until use. Total proteins were extracted from $100 \mathrm{mg}$ ungerminated conidia harvested as

*Corresponding author: Katia Gindro, Agroscope Changins-Wädenswil, P.O. Box 1012, Route de Duillier 50, CH-1260 Nyon, Switzerland, Tel: +41 2236343 74; E-mail: Katia.gindro@agroscope.admin.ch

Received November 03, 2013; Accepted November 20, 2013; Published November 22, 2013

Citation: Schnee S, Rougeux E, Pezet R, Viret O, Gindro K (2013) Evidence for a Constitutive Cutinase in Ungerminated Conidia of Erysiphe necator Schwein. J Cytol Histol 4: 197. doi: 10.4172/2157-7099.1000197

Copyright: @ 2013 Schnee S, et al. This is an open-access article distributed under the terms of the Creative Commons Attribution License, which permits unrestricted use, distribution, and reproduction in any medium, provided the original author and source are credited. 
described above. Conidia were mixed with $2 \mathrm{~g}$ of glass beads $(1 \mathrm{~g} \varnothing 0.25$ $0.30 \mathrm{~mm}$ and $1 \mathrm{~g} \varnothing 0.17-0.18 \mathrm{~mm}$ ), freeze dried under liquid nitrogen and stirred during $30 \mathrm{~s}$. Conidia and glass beads were then suspended in $10 \mathrm{ml}$ phosphate buffer $1 \mathrm{M} \mathrm{pH}$ 7.5. Proteins were extracted according to the method of Van Etten and Freer for $30 \mathrm{~min}$ [15]. The crude protein extract was centrifuged $\left(10,000 \mathrm{rpm}, 4^{\circ} \mathrm{C}, 10 \mathrm{~min}\right)$. The supernatant, corresponding to the cytoplasmic protein extract (CPE) was placed in dialysis tubing, concentrated to $1 \mathrm{ml}$ in PEG, filtered $(0.2 \mu \mathrm{m}$, Akrodisk Nalgene) and stored at $-20^{\circ} \mathrm{C}$ until use. The culot, corresponding to remaining parietal proteins (RPP), was suspended in $10 \mathrm{ml}$ phosphate buffer $1 \mathrm{M}$ pH 7.5 containing $1 \%$ Triton X-100 and incubated at $4^{\circ} \mathrm{C}$ during 24 hours. This extract was placed in dialysis tubing, concentrated to $1 \mathrm{ml}$ in PEG, filtered $(0.2 \mu \mathrm{m}$, Akrodisk Nalgene $)$ and stored at $-20^{\circ} \mathrm{C}$ until use. Microscopic examination showed that $>95 \%$ of the conidia were broken. Proteins were determined by the Bradford method. Non-specific esterase activity was spectrophotometrically measured using para-nitrophenyl butyrate (PNB) [16], and cutinase activity was determined using $\left({ }^{3} \mathrm{H}\right)$ tomato cutin, as previously reported [17]. Pure tomato cutin was prepared according to Salinas et al. [18] and labelled with $\left({ }^{3} \mathrm{H}\right) \mathrm{NaBH}_{4}\left(3.7 \times 10^{9} \mathrm{~Bq} ; 5.2 \times 10^{11} \mathrm{~Bq} \mathrm{mmol}^{-1}\right)$ according to Koller et al. [19]. $\left({ }^{3} \mathrm{H}\right)$ cutin was chemically depolymerised using $0.5 \mathrm{M}$ methanolic $\mathrm{NaOH}$ under $\mathrm{N}_{2}$ [18]. The radioactivity of the fatty acids released from enzymatically and chemically depolymerised $\left({ }^{3} \mathrm{H}\right)$ cutin was measured in a scintillation counter (Intertechnique SL-30).

\section{Histochemical localisation of esterase activity}

Histological localisation of esterase activity in conidia was determined with indoxyl acetate as a substrate, as described previously [5] with slight modifications. The medium was placed on glass slides. A first batch of slides were inoculated with fresh conidia from sporulating grapevine leaves by blowing on the medium with a labour mini-pump as described above. The other was inoculated with washed conidia according to the following method: conidia $(5 \mathrm{mg})$ were washed in water with $2 \%$ Triton X-100 during $1 \mathrm{~h}$ and washed 5 times in distilled water by centrifugation $\left(10,000 \mathrm{rpm}, 4^{\circ} \mathrm{C}, 1 \mathrm{~min}\right)$. The supernatant was discarded and conidia were suspended in $1 \mathrm{ml}$ of sterile distilled water. This suspension was filtered through a $0.45 \mu \mathrm{m}$ filter, dried and conidia were blown on slides as described before. Slides were incubated for $24 \mathrm{~h}$ in humid chambers and observed with a bright field microscope equipped with a digital camera (Leica DC 100). As a control, ungerminated conidia were autoclaved for $20 \mathrm{~min}$ at $120^{\circ} \mathrm{C}$ and treated as previously described.

\section{Scanning electron microscopy (SEM)}

Leaf discs (1-cm diameter) were excised from infected Vitis leaves $12 \mathrm{~h}$ after inoculation and fixed with osmium tetroxide vapours (aqueous solution of $2 \% \mathrm{OsO}_{4}(\mathrm{w} / \mathrm{v})$ and $3 \% \mathrm{CrO}_{3}(\mathrm{w} / \mathrm{v})$ ) for $4 \mathrm{~h}$ at room temperature in a closed humid chamber. They were then dehydrated in a graded series of acetone (10, 30, 50, 70, 90 and 100\% (v/v); $20 \mathrm{~min}$ on ice for each step), dried in $\mathrm{CO}_{2}$ according to the critical point drying method (Critical Point Dryer, Baltech) and coated with gold. The samples were observed at $5 \mathrm{kV}$ using scanning electron microscopy (Jeol JSM-6300 F). To investigate the importance of cutinase and esterase in the process of cutin degradation, leaves of grapevine were sprayed with a $5 \mu \mathrm{M}$ solution of the inhibitor diisopropyl fluorophosphate (DIPF) according to the method of Deising et al. [5]. The leaves were allowed to dry before the inoculation of dry conidia. Leaf discs were excised 12 $\mathrm{h}$ after inoculation and treated as described before.

\section{Results}

A non-specific esterase activity was measured in the cell wall protein extract (PPE) of ungerminated conidia, as well as in the remaining parietal protein fraction from broken conidia (RPP). No activity was detectable in the cytoplasmic protein extract (CPE) (Table 1). Each active extract was further used to determine if the non-specific esterase activity is a cutinase activity by using $\left({ }^{3} \mathrm{H}\right)$-cutin as a hydrolysis substrate. The enzymatic activity of the parietal protein extract (PPE) as well as the remaining parietal protein extract from broken conidia released up to four-fold more labelled fatty acid monomers than the control, indicating the presence of a specific, constitutive cutinase activity in the cell wall protein extract of ungerminated conidia of $E$. necator (Table 2). The cytoplasmic protein extract (CPE) was similar to the control, displaying no specific cutinase or esterase activity for the cytoplasm of ungerminated conidia.

Histochemical localisation of cutinase activity in conidia was determined on an agar medium containing the non-specific esterase substrate indoxyl acetate (Figure 1). Intact, fresh, ungerminated conidia

\begin{tabular}{|c|c|c|}
\hline Protein extract & Protein $\left(\mathrm{mg} \mathrm{ml}^{-1}\right)$ & Activity ( $\mu \mathrm{mol} \mathrm{min}^{-1} \mu \mathrm{g}^{-1}$ proteins) \\
\hline PPE & $2.05( \pm 0.31)$ & $0.82( \pm 0.08)$ \\
\hline CPE & $2.25( \pm 0.22)$ & $0.00( \pm 0.00)$ \\
\hline RPP & $1.37( \pm 0.11)$ & $0.80( \pm 0.06)$ \\
\hline
\end{tabular}

Table 1: Non-specific esterase activity measured in parietal (PPE), cytoplasmic (CPE) and remaining parietal (RPP) protein extracts in ungerminated conidia of Erysiphe necator.

\begin{tabular}{|c|c|}
\hline Sample & Activity $\left(\mathrm{cpm}^{*} \times 10^{6}\right)$ \\
\hline Control & $2.152( \pm 0.003)$ \\
\hline Enzymatic depolymerisation with PPE & $10.418( \pm 0.017)$ \\
\hline Enzymatic depolymerisation with RPP & $9.962( \pm 0.015)$ \\
\hline
\end{tabular}

"cpm: counts per minute.

Table 2: Quantification of radioactively labelled cutin monomers released in the presence of parietal protein extract (PPE) and remaining parietal protein extracts (RPP) of ungerminated conidia of Erysiphe necator.

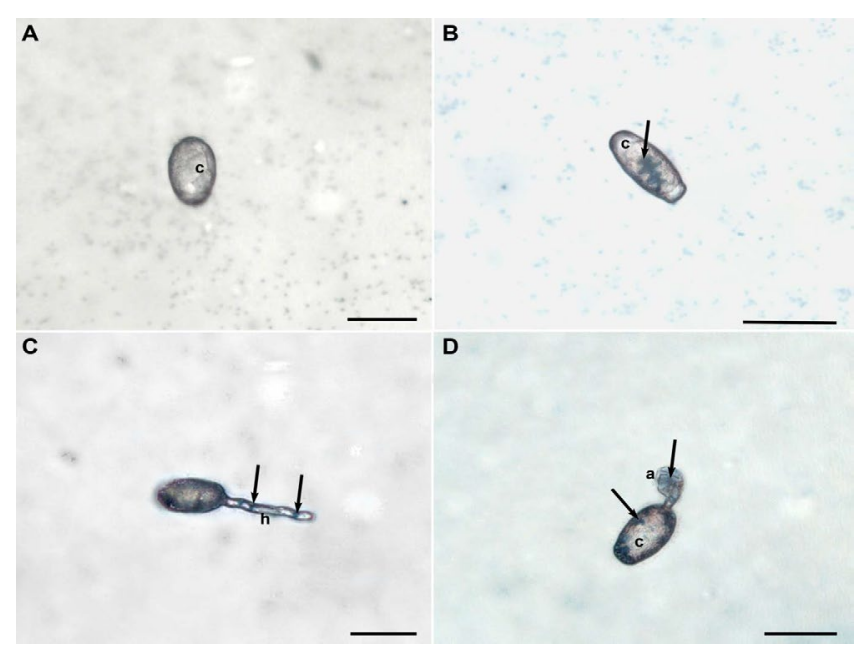

Figure 1: Histochemical localisation of esterase activity in infectious structures of Erysiphe necator by optical microscopy after deposition on artificial medium containing indoxyl acetate. (A) Heat-killed conidium displaying no indigo blue crystals. (B) Ungerminated conidium showing indigo blue crystals (arrow). (C) Conidium and germ tube displaying indigo blue crystals (arrows). (D) Conidium and appressorium displaying indigo blue crystals (arrows); the blue colour is present in the overall appressorium. a: appressorium, c: conidium, and $\mathrm{h}$ : hypha. Scale bars represent $30 \mu \mathrm{m}$. 


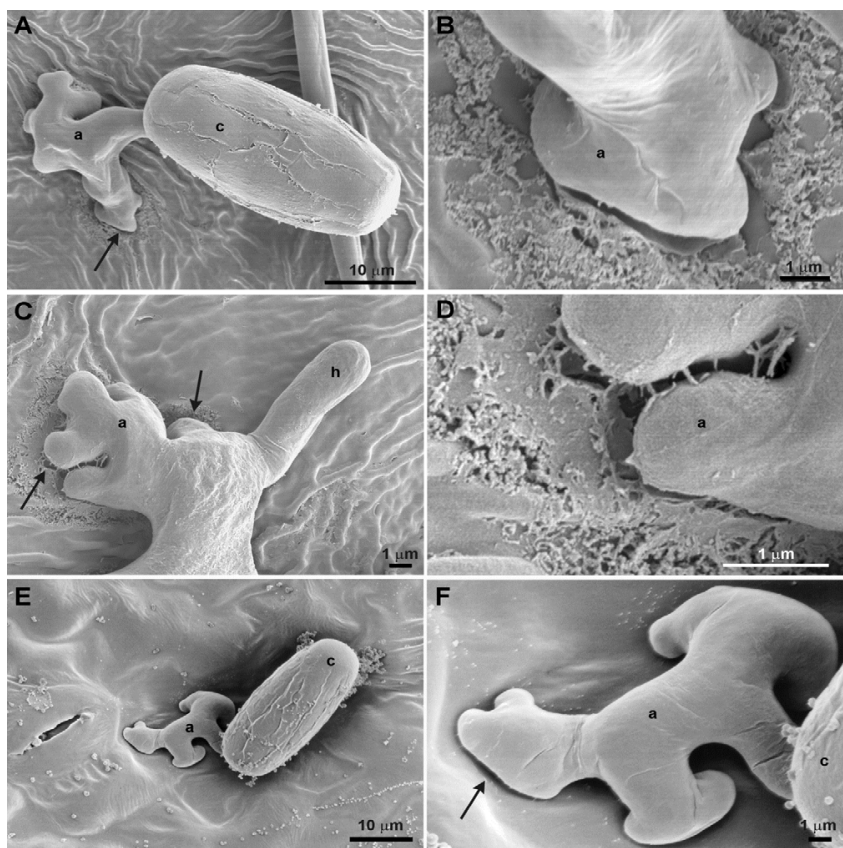

Figure 2: Degradation of the cuticular layer of Vitis vinifera cv. Chasselas upon contact with infectious structures of Erysiphe necator observed by scanning electron microscopy. (A) Appressorium formation from a conidium and the first step of cuticular degradation (arrow). (B) Detail of the zone of contact of the appressorium with the cuticular layer, which is partially depolymerised. (C) Functional appressorium displaying active degradation of the cuticular layer (arrows) and the developing primary hypha. (D) Detail of $C$ showing an important erosion of the cuticular surface. (E) Leaves pre-treated with the inhibitor DIPF showing no cuticular degradation neither under the conidium nor the appressorium. (F) Detail of $(E)$ showing no erosion of the cuticular surface (arrow). a: appressorium, c: conidium, and h: hypha.

displayed indigo blue crystals, indicating the presence of functional esterases. No formation of blue crystals appeared in the conidial cytoplasm. Washed conidia did not exhibit any blue crystals indicating that esterases were eliminated during the washing process. Heat-killed conidia remained hyaline after substrate contact, indicating inactivation of esterases at $120^{\circ} \mathrm{C}$. Moreover, after germination, formation of indigo blue crystals could be followed along the germ tube and at its apex during appressorium and hyphal development. When fresh conidia were sprayed on grape cutin, the area between the appressorium peg and the host surface was altered, showing localised enzymatic degradation and erosion of the cuticular surface (Figure 2). A mucilaginous sheath was observed in close proximity to the appressorium but not along the differentiated hyphal tip. In the case of pre-treated leaves with the inhibitor of serine hydrolases DIPF, no such degradation was observed neither under the conidia nor the appressoria (Figures $2 \mathrm{E}$ and $2 \mathrm{~F}$ ). Moreover, the development of E. necator on DIPF pre-treated leaves stopped after the formation of the first appressorium without any further development (data not shown).

\section{Discussion}

The infection process of plant fungal pathogens follows a strict chronological sequence during which each fungal morphological differentiation plays a functional role in host colonisation. The determination of a constitutive cell wall cutinase in ungerminated conidia of Erysiphe necator, combined with esterase activity in growing hyphae, constitute a new cue to better understand the infection mechanisms of susceptible varieties of Vitis vinifera by E. necator.
Mucilaginous material localised in a specific zone of host-plant pathogen interaction contains non-specific esterases and, sometimes, cutinases [5,17]. Indeed, cutinases were identified in exudates of Blumeria graminis [11]. In the present work, the occurrence of an extracellular matrix in the vicinity of the appressoria was observed by SEM. A previous report [20] identified a similar matrix under the appressoria developing on artificial substrates, indicating the fungal origin of such material. Moreover, the alteration of the plant cuticle observed by SEM could signify that the material released from the enzymatic hydrolysis of the cutin partially forms the matrix, improving the adhesion of fungal structures. This is confirmed by the use of DIPF as serine hydrolase inhibitor which inhibits the enzymatic activity linked to the degradation of the cuticular material in the vicinity of the conidia and primary infectious structures as shown before in Blumeria graminis [21]. However, the use of esterase and cutinase inhibitors does not affect the adhesion of conidia on grapevine cuticle as previously shown [20], suggesting that other molecules exhibiting adhesive properties, such as polysaccharides, proteins or glycoproteins, are secreted [22]. In Botrytis cinerea, the extracellular matrix permits the adhesion of conidia to hydrophilic or hydrophobic substrates containing glucose, proteins and galactosamine [23]. In the E. necator-Vitis vinifera interaction, the adhesion of fungal structures to the host surface remains closely linked to the development of specific infectious structures [20]. The contact area between the appressorium and the cuticle represents an efficient way to anchor the pathogen to the host. These authors demonstrate that abundant washings do not remove the appressoria, which remain firmly attached, whereas conidia break at the site of germ tube formation and are eliminated.

In the present study, a constitutive parietal cutinase activity in ungerminated conidia was established by the hydrolysis of radioactively labelled cutin. A previous study [7] describes an important esterase activity in ungerminated and germinated conidia of E. graminis. In $B$. cinerea, a cytoplasmic cutinase activity is expressed during germination and further mycelium development $[18,24]$. The parietal localisation of esterase activity is in accordance with previous observations in $E$. necator [20] and other pythopathogenic fungi, such as E. graminis [6] and Uromyces vicia-fabae [5]. The constitutive esterase of the ungerminated conidia of $E$. necator is excreted upon contact with the cuticular surface during the primary infection steps [25]. In E. necator, the reticulated structure of the outer surface of the conidia increases the contact zone with the host. A weak quantity of extracellular material originates from the decorations of the conidia upon contact with the host surface in Blumeria graminis f. sp. hordei [26].

The results of the present study suggest that $E$. necator releases a low amount of parietal cutinase upon contact with the host surface, sufficient to initiate the hydrolysis of cutin and to permit the further development of infectious fungal structures.

As shown previously in Fusarium solani and Venturia inaequalis, the synthesis of cutinolytic enzymes can be induced by a low concentration of cutin monomers $[8,25]$. Different esterase isoenzymes have been identified in Curvularia eragrostidis whose release is mediated by epicuticular waxes [4], consequently modifying the virulence of the pathogen according to the host plant. In this respect, the cutinase family may be linked to virulence factors, as recently demonstrated in the genus Phytophthora [27]. The cutin monomers lead to the activation of cutinase genes implicated in further infection steps, such as the differentiation of appressoria [28]. Cutinase genes have also been identified in several fungal species, but their roles in pathogenesis are under investigation [29,30]. In Magnaporthe grisea, the CUT2 
Citation: Schnee S, Rougeux E, Pezet R, Viret O, Gindro K (2013) Evidence for a Constitutive Cutinase in Ungerminated Conidia of Erysiphe necator Schwein. J Cytol Histol 4: 197. doi: 10.4172/2157-7099.1000197

cutinase gene is over-expressed during appressorium maturation and host penetration [31]. The inhibition of this enzyme in a mutant strain drastically reduces the virulence of this pathogen on rice and wheat. We hypothesise that the esterase activity of ungerminated conidia of E. necator hydrolyses specific cuticular wax esters, which in turn may activate the synthesis of other esterases and serine esterases.

The activity of hydrolytic enzymes, such as esterases and cutinases, in the primary infection step of E. necator on grapevine could constitute one key factor in successful host penetration and trophic interaction.

\section{Acknowledgments}

The authors thank Mr. Eric Remolif for plant production as well as Dr Eric Rosset (HEPIA, Geneva) for the production of the cyclone filter. We gratefully acknowledge the first nine Grands Crus de Bordeaux (Bordeaux, France) for their financial support: château Ausone, château Cheval blanc, château Haut-Brion, château Lafitte Rothschild, château Latour, château Margaux, château Mouton Rothschild, château Petrus and château d'Yquem.

\section{References}

1. Pio TF, Macedo GA (2009) Cutinases: properties and industrial applications Adv Appl Microbiol 66: 77-95.

2. Chen S, Tong X, Woodard RW, Du G, Wu J, et al. (2008) Identification and characterization of bacterial cutinase. J Biol Chem 283: 25854-25862.

3. Baker CJ, Bateman DF (1978) Cutin degradation by plant pathogenic fungi. Phytopathology 68: 1577-1584.

4. Wang F, Zhang P, Qiang S, Xu L-L (2006) Interaction of plant epicuticular waxes and extracellular esterases of Curvularia eragrostidis during infection of Digitaria sanguinalis and Festuca arundinacea by the fungus. Int J Mol Sci 7: 346-357.

5. Deising H, Nicholson RL, Haug M, Howard RJ, Mendgen K (1992)Adhesion Pad Formation and the Involvement of Cutinase and Esterases in the Attachment of Uredospores to the Host Cuticle. Plant Cell 4: 1101-1111.

6. Nicholson RL, Yoshioka H, Yamaoka N, Kunoh H (1988) Preparation of the infection court by Erysiphe graminis. II. Release of esterase enzyme from conidia in response to a contact stimulus. Experimental Mycology 12: 336-349.

7. Fric F, Wolf $G$ (1994) Hydrolytic enzymes of ungerminated and germinated conidia of Erysiphe graminis DC f.sp. hordei marchal. Journal of Phytopathology 140: 1-10.

8. Kolattukudy PE, Li DX, Hwang CS, Flaishman MA (1995) Host signals in fungal gene-expression involved in penetration into the host. Canadian Journal of Botany 73: 1160-1168.

9. Gilbert RD, Johnson AM, Dean RA (1996) Chemical signals responsible for appressorium formation in the rice blast fungus Magnaporthe grisea. Physiological and Molecular Plant Pathology 48: 335-346.

10. Heintz C, Blaich R (1990) Ultrastructural and histochemical studies on interactions between Vitis vinifera and Uncinula necator (Schw) Burr New Phytologist 115: 107-117.

11. Pascholati SF, Yoshioka H, Kunoh H, Nicholson RL (1992) Preparation of the infection court by Erysiphe graminis f.sp hordei - cutinase is a component of the conidial exudate. Physiological and Molecular Plant Pathology 41: 53-59.

12. Pezet R, Gindro K, Viret O, Richter H (2004) Effects of resveratrol, viniferins and pterostilbene on Plasmopara viticola zoospore mobility and disease development. Vitis 43: 145-148.

13. Pont V, Pezet R (1990) Relation between the chemical-structure and the biological-activity of hydroxystilbenes against Botrytis cinerea. Journal of Phytopathology 130: 1-8.

14. Chen B, Feather GA, Maynard A, Rao CY (2004) Development of a personal sampler for collecting fungal spores. Aerosol Science and Technology 38: 926 937.

15. Van Etten JL, Freer SN (1978) Simple procedure for disruption of fungal spores Appl Environ Microbiol 35: 622-623.

16. Huggins C, Lapides J (1947) Chromogenic substrates. 4. Acyl esters of paranitrophenol as substrates for the colorimetric determination of esterase. Journal of Biological Chemistry 170: 467-482.

17. Pascholati SF, Deising H, Leite B, Anderson D, Nicholson RL (1993) Cutinase and non-specific esterase activities in the conidial mucilage of Colletotrichum graminicola. Physiological and Molecular Plant Pathology 42: 37-51.

18. Salinas J, Warnaar F, Verhoeff K (1986) Production of cutin hydrolyzing enzymes by Botrytis cinerea in vitro. Journal of Phytopathology 116: 299-307.

19. Koller W, Allan CR, Kolattukudy PE (1982) Role of cutinase and cell wall degrading enzymes in infection of Pisum sativum by Fusarium solani f.sp pisi. Physiological Plant Pathology 20: 47-52.

20. Rumbolz J, Kassemeyer HH, Steinmetz V, Deising HB, Mendgen K, et al (2000) Differentiation of infection structures of the powdery mildew fungus Uncinula necator and adhesion to the host cuticle. Canadian Journal of Botany 78: 409-421.

21. Feng J, Wang F, Hughes GR, Kaminskyj S, Wei Y (2011) An important role for secreted esterase in disease establishment of the wheat powdery mildew fungus Blumeria graminis f. sp. tritici. Can J Microbiol 57: 211-216.

22. Jones EBG (1994) Fungal adhesion. Mycological Research 98: 961-981.

23. Doss RP, Potter SW, Soeldner AH, Christian JK, Fukunaga LE (1995) Adhesion of germlings of Botrytis cinerea. Appl Environ Microbiol 61: 260-265.

24. Gindro K, Pezet R (1997) Evidence for a constitutive cytoplasmic cutinase in ungerminated conidia of Botrytis cinerea Pers.: Fr. Fems Microbiology Letters 149: 89-92.

25. Koller W, Parker DM, Becker CM (1991) Role of cutinase in the penetration of apple leaves by Venturia inaequalis. Phytopathology 81: 1375-1379.

26. Carver TLW, Kunoh H, Thomas BJ, Nicholson RL (1999) Release and visualization of the extracellular matrix of conidia of Blumeria graminis. Mycological Research 103: 547-560.

27. Belbahri L, Calmin G, Mauch F, Andersson JO (2008) Evolution of the cutinase gene family: evidence for lateral gene transfer of a candidate Phytophthora virulence factor. Gene 408: 1-8.

28. Kolattukudy PE, Podila GK, Mohan R (1989) Molecular basis of the early events in plant fungus interaction. Genome 31: 342-349.

29. Rubio MB, Cardoza RE, Hermosa R, Gutiérrez S, Monte E (2008) Cloning and characterization of the Thcut 1 gene encoding a cutinase of Trichoderma harzianum T34. Curr Genet 54: 301-312.

30. Bashi ZD, Rimmer SR, Khachatourians GG, Hegedus DD (2012) Factors governing the regulation of Sclerotinia sclerotiorum cutinase $A$ and polygalacturonase 1 during different stages of infection. Canadian Journal of Microbiology 58: 605-616.

31. Skamnioti P, Gurr SJ (2007) Magnaporthe grisea cutinase2 mediates appressorium differentiation and host penetration and is required for full virulence. Plant Cell 19: 2674-2689. 